\title{
The Effects of Specific Stretching Exercises on Flexibility and Balance Parameters in Gymnastics
}

\author{
Ömer Özer ${ }^{1} \&$ Recep Soslu ${ }^{1}$ \\ ${ }^{1}$ Physical Education and Sport, Karamanoğlu Mehmetbey University, Karaman, Turkey \\ Correspondence: Ömer Özer, Physical Education and Sport, Karamanoğlu Mehmetbey University, Karaman, \\ Turkey. E-mail: besyo4307@gmail.com
}

\author{
Received: July 24, 2019 Accepted: August 16, $2019 \quad$ Online Published: September 20, 2019 \\ doi:10.5539/jel.v8n5p136 URL: https://doi.org/10.5539/jel.v8n5p136
}

\begin{abstract}
This study was planned to examine the effect of Gymnastics-specific stretching exercises on flexibility and balance parameters. A total of 28 ( 16 males, 12 females) volunteer students were involved in the study, who were educated at the School of Physical Education and Sports. For 12 Weeks, 2 days a week and 90 min. stretching exercises specific to the gymnastics branch were applied and flexibility (sit-lie down) and $\mathrm{Y}$ balance tests were applied before the study. Anova test analysis was used to determine the difference between pre-test and post-test. Although the SA (right foot anterior), SPL (right foot posterolateral), SPM (right foot posteromedial), SLA (left foot anterior), SLPL (left foot posterolateral), SLPM (left foot posteromedial) scores of male and female students in the study showed a positive increase compared to the preliminary test scores, there was no statistically significant difference $(\mathrm{p}>.05)$. As a result, gymnastic branch-specific stretching exercises increase the balance and flexibility parameters in a positive way; it is thought that the longer duration of training programs will have a positive effect on the athlete's performance.
\end{abstract}

Keywords: gymnastics, stretching exercises, flexibility, balance

\section{Introduction}

Gymnastics is a sports branch that provides the complex technical movements necessary for each sports branch and contains many motoric features (Atılgan \& Pinar, 2005). As with most sports branches, gymnastics requires high physical technical skill physiological performance (Tatlici \& Cakmakci, 2019). It consists of many movements and movement groups such as Jump, capriole, turn, armstand dvies, leg and arm tossing, flight, static and dynamic posture (Akdogan, 2008). These movement groups consist of various combination repeats and are performed at the limits of the athletes' anatomical joint angle range (Savucu et al., 2018). Skills require that the area of movement of the joints from a biomechanical point of view be made at the most efficient angles, with muscle, tendon, and joint capsules having enough flexibility (Pope et al., 2000; Karataş, 2017). Connective tissue flexibility improves musculoskeletal sensitivity, joint movement width, and muscular performance (Polloc et al., 1998). Stretching exercises to increase flexibility are routinely included in both the training program and warm-up activities of many athletes. As stated at the basic level, the whole body should be considered as a whole in flexibility studies and should be developed on the basis of general mobility, especially in the specific mobility required for gymnasts.

When gymnasts perform acrobatic movements, they must constantly move their body from one position to the other. They, therefore, have to maintain their dynamic and static balance in the best way (Asseman, 2004). Because the smallest loss of balance will negatively affect the score the athlete will receive, balance in gymnastics is an important factor and one of the most important features that need to be developed (Attlgan et al., 2012). Balance is the ability to control the body with minimal muscle activity in static and dynamic positions against changes in the body's center of gravity (Akyüz, 2017). It suggests that age and maturation may have an effect on the amalgamation of selected balance components and lower limb muscle strength (Akyüz et al., 2017). The common view is that balance ability is a different indicator of sportive performance in sports requiring static and dynamic performance and that different methods and evaluation protocols are applied in assessing balance (Ateş et al., 2017). The balance is divided into two types: static and dynamic. Static balance is the ability of the body to maintain balance in a certain place or position, while the dynamic balance is the ability to maintain the balance of the whole or part of the body in motion (Kuşakoğlu, 2012; Aslan et al., 2018). 
Stretching exercises are used in gymnastics branch where balance and flexibility are very important, but when the literature is examined, there are not enough studies about the training programs of stretching exercises. From this point of view, our study is planned to determine the effect of flexibility and balance parameters of gymnastic stretching exercises for 12 weeks.

\section{Method}

\subsection{Sample and Procedure}

A total of 28 (16 males, 12 females) volunteer students from the School of Physical Education and Sports of Karamanoğlu Mehmetbey University participated in the study. The age, length, weight and leg lengths of the male and female students in the study group are shown in table1, respectively.

Table1. Age, height, weight and leg length values of male and female students

\begin{tabular}{lllll}
\hline Gender & Old (year) & Size $(\mathrm{cm})$ & Weight $(\mathrm{kg})$ & Leg Length $(\mathrm{cm})$ \\
\hline Man & $20.5 \pm 3.01$ & $176 \pm 5.53$ & $68.37 \pm 9.15$ & $95.06 \pm 7.94$ \\
Woman & $19.75 \pm 1.06$ & $153.14 \pm 47.98$ & $56.25 \pm 6.96$ & $91.88 \pm 4.76$ \\
\hline
\end{tabular}

The mean age of male students was $20.5 \pm 3.01$ years, mean age of female students was $19.75 \pm 1.06$ years, mean length of male students was $176 \pm 5.53 \mathrm{~cm}$, mean length of female students was $153.14 \pm 47.98 \mathrm{~cm}$, mean body weight of male students was $68.37 \pm 9.15 \mathrm{~kg}$, mean body weight of female students was $56.25 \pm 6.96 \mathrm{~kg}$, mean leg length of male students was $95.06 \pm 7.94 \mathrm{~cm}$ and mean leg length of female students was $91.88 \pm 4.76 \mathrm{~cm}$.

\subsection{Exercise Protocol}

Stretching exercise program was applied to the study group for 12 weeks, 2 days a week and 90 minutes. Movements in unit training were completed in 4 sets. In order to correct movements and correct errors before the application, a 1-Week adaptation program was applied before the start of the program and flexibility and balance tests were applied to the Working Group before and after the 12-week stretching exercise program.

Table 2. 12-week stretching exercise program

\begin{tabular}{lllll}
\hline Exercises & 1.Rep & 2.Rep & 3.Rep & 4.Rep \\
\hline All fours walk & $20 \mathrm{~m}$ & $20 \mathrm{~m}$ & $20 \mathrm{~m}$ & $20 \mathrm{~m}$ \\
Right Hand Right Foot Walk & $20 \mathrm{~m}$ & $20 \mathrm{~m}$ & $20 \mathrm{~m}$ & $20 \mathrm{~m}$ \\
Left Hand Left Foot Walk & & & & \\
Caterpillar Walk & $20 \mathrm{~m}$ & $20 \mathrm{~m}$ & $20 \mathrm{~m}$ & $20 \mathrm{~m}$ \\
Little Bear Walk & $20 \mathrm{~m}$ & $20 \mathrm{~m}$ & $20 \mathrm{~m}$ & $20 \mathrm{~m}$ \\
Bear Walk & $20 \mathrm{~m}$ & $20 \mathrm{~m}$ & $20 \mathrm{~m}$ & $20 \mathrm{~m}$ \\
Little Rabbit Walk & $20 \mathrm{~m}$ & $20 \mathrm{~m}$ & $20 \mathrm{~m}$ & $20 \mathrm{~m}$ \\
Rabbit Walk & $20 \mathrm{~m}$ & $20 \mathrm{~m}$ & $20 \mathrm{~m}$ & $20 \mathrm{~m}$ \\
\hline
\end{tabular}

\subsection{Data Collection Tool}

\subsubsection{Flexibility (Sit-Lie Down) Test}

Sit-lie test was used to determine their flexibility. The top of a $32 \mathrm{~cm}$ high and $35 \mathrm{~cm}$ long table was measured by dividing it into $\mathrm{cm}$. The research group sat on the floor, stretched out their legs and, without shoes, rested their soles on the coffee table. The group was then asked to extend from the trunk (waist and hips) as far as possible on the stand without bending the knees. The most extreme point of the fingers was measured in $\mathrm{cm}$. The research group repeated this three times and the best grade was obtained (Özer \& Kilinc, 2012; Bakırcı \& Kilinc, 2014; Güvern et al., 2017).

\subsubsection{Y-Balance Test}

$\mathrm{Y}$ dynamic balance test is used to measure dynamic balance. The test is applied without shoes. The athlete stands on one foot in the center of balance and extends in the anterior, posteromedial and posterolateral directions with the free foot on one foot 3 access attempts in each direction while standing on the right foot and then 3 access attempts while standing on the left foot. The specific order of the Test (right anterior, left anterior, right posteromedial, left posteromedial, right posterolateral, left posterolateral) is followed. The maximal access distance reached is measured by reading the Strip measurement at the edge of the access indicator. The most successful result reached 
for each direction is used for analysis (Fusco et al., 2019; Yam \& Fong, 2019)

\subsection{Data Analyses}

For statistical calculations of the data obtained, the assumptions of normality, homogeneity of variance and independent observation were checked first with the SPSS 25 computer package program. ANOVA test was used to determine the difference in the pre and post-test for repeated measurements.

\section{Results}

Table 2. Flexibility and Y balance values of male students

\begin{tabular}{lllllllll}
\hline Variables & $\mathrm{N}$ & Flexibility & SA & SPL & SPM & SLA & SLPL & SLPM \\
\hline Pre-test & 16 & $30.03 \pm 8.5$ & $69.83 \pm 10$ & $90.72 \pm 10.2$ & $87.28 \pm 14.4$ & $69.58 \pm 9.4$ & $89.81 \pm 11.3$ & $89.47 \pm 14.5$ \\
Post-test & & $37.13 \pm 13.2$ & $73.25 \pm 10.6$ & $91.47 \pm 9.4$ & $91.44 \pm 10.1$ & $74.69 \pm 8.5$ & $95.94 \pm 8.3$ & $90.47 \pm 10$ \\
\hline
\end{tabular}

Note. SA: (right foot antrerior), SPL: (right foot posterolateral), SPM: (right foot posteromedial), SLA: (left foot anterior), SLPL: (left foot posterolateral), SLPM: (left foot posteromedial).

When Table 2 was examined, the post-test of male students showed a positive increase in SA (right foot anterior), SPL (right foot posterolateral), SPM (right foot posteromedial), SLA (left foot anterior), SLPL (left foot posterolateral), SLPM (left foot posteromedial) scores compared to the preliminary test scores, there was no statistically significant difference $(\mathrm{p}>.05)$.

Table 3. Flexibility and $\mathrm{Y}$ balance values of female students

\begin{tabular}{lllllllll}
\hline Variables & N & Flexibility & SA & SPL & SPM & SLA & SLPL & SLPM \\
\hline Pre-test & 12 & $33.58 \pm 8.14$ & $71.54 \pm 9.54$ & $91.09 \pm 8.85$ & $89.36 \pm 8.12$ & $72.13 \pm 8.12$ & $92.88 \pm 8.33$ & $89.97 \pm 6.84$ \\
Post-test & & $35.35 \pm 8.55$ & $72.39 \pm 3.84$ & $91.28 \pm 8.06$ & $90.40 \pm 5.48$ & $73.41 \pm 4.28$ & $94.41 \pm 7.58$ & $90.22 \pm 7.05$ \\
\hline
\end{tabular}

Table 3 is examined; although the SA (right foot anterior), SPL (right foot posterolateral), SPM (right foot posteromedial), SLA (left foot anterior), SLPL (left foot posterolateral), SLPM (left foot posteromedial) scores of the female students showed a positive increase compared to the preliminary test scores, there was no statistically significant difference $(\mathrm{p}>.05)$.

\section{Discussion}

\subsection{Study Limitations and Implications for Future Assessment}

Physical and mental activities to achieve the highest performance required by competition or training are called warming up integrity (Arslan et al., 2011). When the literature is examined, it is thought that the different types, intensities and periods of warming are caused by the different warming methods used in these studies (Devries \& Housh, 1994; Colak \& Çetin, 2010; Turan \& Çilli, 2016; Harmanci et al., 2017). Siatras et al. (2003) compared 3 different warming methods (warming, static stretching, and dynamic stretching) on Gymnasts and found a statistically significant difference in warming and dynamic stretching methods while finding no significant difference in static stretching method. Çoknaz et al. (2008) they found that the group performing 15 -second, 10-repeat, and 30-second static stretching exercises on non-consecutive days with 15 -second, 10-repeat stretching exercises with two different programs applied on 15-second, 10-repeat stretching exercises had more significant increases in flexibility values. Guidetti et al. (2009) the study of pre-competition warm-up times of Elit and Subelit gymnasts found a statistically significant difference between pre-competition warm-up times of elite and Subelit gymnasts. Çoknaz et al. (2010) in 3 groups of 18 gymnasts who had Joggin and stretching for only 5 minutes examined the effect of acoustic and optical reaction times of gymnasts and no statistically significant difference was detected as a result of the study. Özengin et al. (2011) they applied 2 different static stretching methods on 27 rhythmic gymnasts. They found no statistically significant difference between the pre and post-test results. Siatras (2014) 14 Gymnast on his 3 different warm-up methods respectively a) General warming without stretching b) static stretching with synergist muscles c) Static stretching with antagonist muscles found $a>b$ and $c>b$ statistically significant difference between pre-test and post-test values. The warming model we applied in our study parallels the effect of participants on flexibility parameters with the literature. Especially post-warming gait studies are considered to have a positive effect in terms of preservation of the joint space angle.

Gymnastics branch is a sports branch that requires extensive locomotor movement, balance, flexibility, and body control movements (Ballı \& Gürsoy, 2012). Balance skill is a very important factor in gaining skills such as 
walking, running, jumping (Durukan et al., 2016). Coordination of movements requires a certain balance system (Yüksel \& Akın, 2017; Ünlü \& Tatlıc1, 2018). Ahmadabadi et al. (2015) applied two different protocols consisting of acute and chronic dynamic warming after 10 minutes of running on 16 elite gymnasts and found that the dynamic warming protocol had a statistically significant effect on static and dynamic equilibrium parameters. Belkhiria et al. (2014) conducted two different dynamic and static stretching exercises in 4, 8 and 12 sets on the students who studied Physical Education and Sports Teaching, before and after balance parameters. As a result of their studies, they found that static and dynamic stretching exercises improved the anterior, posterior lateral and posterior medial balance parameters numerically but were not statistically significant. Dallas and Kirialanis (2013) found that there was a statistically significant difference between the balance parameters of the pre-and post-test values of full-body vibration and static stretching methods after full-body vibration on 12 elite gymnasts. Atılgan (2013) ensured that there was a statistically significant difference in static and dynamic balance parameters following his mini-trampoline studies on 28 gymnasts. Di Cagno et al. (2010) in their study on rhythmic gymnasts, they examined 3 different bounce and referee scoring values of the warm-up run and static stretching exercises. As a result of their study, they found that the static stretching Spiers after the warm-up did not have any statistically significant effect on the bounce and referee evaluation scores. Donti et al. (2014) they applied 2 different warming protocols on Elite gymnasts which included short-term and long-term post-stretching bounce studies, and they found that there was a statistically significant difference in the protocol which included long-term post-stretching bounce studies. The warming model we applied in our study parallels the effect of participants on balance parameters with the literature. It is thought that some balance parameters have a positive effect, especially after warm-up walking.

\subsection{Conclusion}

As a result, gymnastic branch-specific stretching exercises increase the balance and flexibility parameters in a positive way; it is thought that the longer duration of training programs will have a positive effect on the athlete's performance.

\section{References}

Ahmadabadi, F., Avandi, S. M., \& Aminian-Far, A. (2015). Acute versus Chronic dynamic warm-up on balance and balance the vault performance in skilled gymnast. International Journal of Applied Exercise Physiology, 4(2), 20-33.

Akdoğan, H. E. (2008). Artistik Cimnastikcilerde Bazı Fiziksel ve Fizyolojik Parametrelerin İncelenmesi. Yüksek Lisans Tezi, Erciyes Üniversitesi. Sağlık Bilimleri Enstitüsü. Kayseri.

Akyüz, M., Özmaden, M., Doğru, Y., Karademir, E., Aydın, Y., \& Hayta, Ü. (2017). Effect of static and dynamic stretching exercises on some physical parameters in young basketball players Genç basketbolcularda statik ve dinamik germe egzersizlerinin bazı fiziksel parametrelere etkisi. Journal of Human Sciences, 14(2), 14921500. https://doi.org/10.14687/jhs.v14i2.4560

Akyüz, Ö. (2017). Effect of Aerobic Loading on Static Balance in Young Athletes. Journal of Education and Training Studies, 5(3), 154-159. https://doi.org/10.11114/jets.v5i3.2177

Arslan, C., Gökhan, İ., \& Aysan, H. A. (2011). Amatör sporcularda ısınma alışkanlığı ve bilgi düzeylerinin değerlendirilmesi. Journal of Clinical and Experimental Investigations, 2(2), 181-186. https://doi.org/10.5799/ahinjs.01.2011.02.0010

Aslan, A. K., Erkmen, N., Aktaş, S., \& Güven, F. (2018). Postural control and functional performance after core training in young soccer players. Malaysian Journal of Movement, Health \& Exercise, 7(2). https://doi.org/10.15282/mohe.v7i2.234

Asseman, F., Caron, O., \& Crémieux, J. (2004). Is there a transfer of postural ability from specific to unspecific postures in elite gymnasts? Neuroscience Letters, 358(2), 83-86. https://doi.org/10.1016/j.neulet.2003.12.102

Ateş, B., Çetin, E., \& Yarım, İ. (2017). Kadın sporcularda denge yeteneği ve denge antrenmanları. Gaziantep Üniversitesi Spor Bilimleri Dergisi, 2(2), 66-79.

Atılgan, O. E. (2013). Effects Of Trampolıne Traınıng On Jump, Leg Strength, Statıc And Dynamıc Balance Of Boys. Science of Gymnastics Journal, 5(2).

Atılgan, O. E., Akın, M., Alpkaya, U., \& Pınar, S. (2012). Investigating of relationship between balance parameters and balance lost of elite gymnastics on balance beam. Journal of Human Sciences, 9(2), 1260 1271. 
Atılgan, O. E., \& Pınar, S. (2005). Ritm Eğitiminin Kompleks Cimnastik Beceri Öğrenimi Üzerine Etkisinin Değerlendirilmesi. Gazi Beden Eğitimi Ve Spor Bilimleri Dergisi, 10(2), 11-24.

Bakırcı, A., \& Kılınç, F. (2014). Hazırlık Periyodunda Uygulanan Kombine Antrenmanların Üniversite Basketbol Takımının Performans Düzeyine Etkisi. İnönü Üniversitesi Beden Eğitimi Ve Spor Bilimleri Dergisi, 1(2), $48-67$.

Ballı, Ö. M., \& Gürsoy, F. (2012). Bruininks-Oseretsky Motor Yeterlik Testinin Beş-Altı yaş Grubu Türk Çocuklar İ̧̧in Geçerlik Ve Güvenirlik Çalışması. Spor Bilimleri Dergisi, 23(3), 104-118.

Belkhiria-Turki, L., Chaouachi, A., Turki, O., Hammami, R., Chtara, M., Amri, M., ... \& Behm, D. G. (2014). Greater volumes of static and dynamic stretching within a warm-up do not impair star excursion balance performance. J Sports Med Phys Fitness, 54(3), 279-288.

Çoknaz, H., Veli, G., \& Türkdoğan, Ş. (2010). Artistik Cimnastikçilerde Farklı Isınma Sürelerinin Akustik ve Optik Reaksiyon Sürelerine Etkisi. Beden Eğitimi ve Spor Bilimleri Dergisi, 7(2).

Çoknaz, H., Yıldırım, N. Ü., \&Özengin, N. (2008). Artistik Cimnastikcilerde Farklı Germe Sürelerinin Performansa Etkisi. Spormetre Beden Eğitimi ve Spor Bilimleri Dergisi, 6(3), 151-157. https://doi.org/10.1501/Sporm_0000000100

Çolak, M., \& Çetin, E. (2010). "Bayanlara Uygulanan Farklı Isınma Protokollerinin Eklem Hareket Genişliği ve Esneklik Üzerine Etkileri” FÜ Sağ Tıp Derg. 24. Fırat Üniversitesi Să̆llk Bilimleri Tip Dergisi, 24(1), 001008.

Dallas, G., \& Kirialanis, P. (2013). The Effect Of Two Different Conditions Of Whole-Body Vibration On Flexibility And Jumping Performance On Artıstic Gymnasts. Science of Gymnastics Journal, 5(2).

DeVries, H. A., \& Housh, T. J. (1994). Physiology of Exercise (p. 528). Brown and Benchmark Publishers Dubuque, Iowa.

Di Cagno, A., Baldari, C., Battaglia, C., Gallotta, M. C., Videira, M., Piazza, M., \& Guidetti, L. (2010). Preexercise static stretching effect on leaping performance in elite rhythmic gymnasts. The Journal of Strength \& Conditioning Research, 24(8), 1995-2000. https://doi.org/10.1519/JSC.0b013e3181e34811

Donti, O., Tsolakis, C., \& Bogdanis, G. C. (2014). Effects of baseline levels of flexibility and vertical jump ability on performance following different volumes of static stretching and potentiating exercises in elite gymnasts. Journal of Sports Science \& Medicine, 13(1), 105.

Durukan, H., Koyuncuoğlu, K., \& Şentürk, U. (2016). Okul Öncesi Çocuklarda Temel Cimnastik Programının Motor Gelişim Açısından İncelenmesi. CBÜ Beden Eğitimi ve Spor Bilimleri Dergisi, 11(2), 131-140.

Faruk G., Abdurrahman I., Samet A., Selahattin., Ahmet, Y., \& Yusuf, E. (2017). Effects of badminton training on some physical parameters in badminton players aged 10 to 12 years. Turkish Journal of Sport and Exercise, 19(3), 345-349.

Fusco, A., Giancotti, G. F., Fuchs, P. X., Wagner, H., Varalda, C., \& Cortis, C. (2019). Wobble board balance assessment in subjects with chronic ankle instability. Gait \& Posture, 68, 352-356. https://doi.org/10.1016/j.gaitpost.2018.12.017

Guidetti, L., Di Cagno, A., Gallotta, M. C., Battaglia, C., Piazza, M., \& Baldari, C. (2009). Precompetition warm-up in elite and subelite rhythmic gymnastics. The Journal of Strength \& Conditioning Research, 23(6), 1877-1882. https://doi.org/10.1519/JSC.0b013e3181b3e04e

Harmanc1, H., Karavelioğlu, M. B., Ersoy, A., Yüksel, O., Erzeybek, M. S., \& Başkaya, G.(2017). Post Aktivasyon Potansiyel (Pap) Ve Statik Germe Modeli Isınmalarının Sıçrama Performansına Etkisi. Sportif Bakış: Spor ve Eğitim Bilimleri Dergisi, 4(2), 56-68.

Karataş, M. (2017). 6-7 Yaş Gurubu Erkek Çocuklarda 12 Haftalık Temel Cimnastik Eğitiminin Fiziksel Uygunlukları Üzerine Etkisi. T.C. Fırat Üniversitesi Sağlık Bilimleri Enstitüsü Beden Eğitimi Ve Spor Ana Bilim Dalı. Yüksek Lisans Tezi. Elazı̆̆

Kuşakoğlu, Ö. (2012). Adölesan Dönemde Farkl Yaş Gruplarındaki Erkek Futbolcularda Çevikliğin Değerlendirilmesi. Fizyoterapi ve Rehabilitasyon Yüksek Lisans Programı, İstanbul Bilim Üniversitesi, İstanbul

Muehlbauer, T., Gollhofer, A., \& Granacher, U. (2015). Associations between measures of balance and lower-extremity muscle strength/power in healthy individuals across the lifespan: a systematic review and 
meta-analysis. Sports Med., 45, 1671-1692. https://doi.org/10.1007/s40279-015-0390-z

Özer, Ö., \& Kılınç, F. (2012) Elite athletes in individual and team strength, speed and flexibility to compare their performance. International J Human Sciences, 9(1), 360-371

Özengin, N., Yıldırım, N. Ü., Baltacı, G., \& Masiulis, N. (2011). Acute effects of different stretching durations on vertical jump performance in rhythmic gymnasts. Baltic Journal of Sport and Health Sciences, 3(82). https://doi.org/10.33607/bjshs.v3i82.316

Polloc, M. L., Gaesser, G. A., Butcher, J. D. et al. (1998) The recommended quantity and quality of exercise for developing and maintaining cardiorespiratory and muscular fitness and flexibility in healthy adults. Med Sci Sports Exerc, 30, 975-991. https://doi.org/10.1097/00005768-199806000-00032

Pope, R., Herber, R., Kirwan, J., \& Grahan, B. J. (2000). Arandomized trial of pre-exercise stretching for prevention of lower limb injury. Med Sci Sports Exer, 32, 271-277. https://doi.org/10.1097/00005768-200002000-00004

Savucu, Y., Karataş, M., Eskiyecek, C. G., Yücel, A. S., \& Karadağ, M. (2018). 6-7 Yaş Gurubu Erkek Çocuklarda 12 Haftalık Temel Cimnastik Eğitiminin Fiziksel Uygunluklarına Etkisi. Turkish Journal of Educational Studies, 5(3). https://doi.org/10.33907/turkjes.451340

Siatras, T. (2014). Synergist And Antagonıst Muscles Statıc Stretching Acute Effect Durıng A V-Sit Position On Parallel Bars. Science Of Gymnastics Journal, 6(3), 49.

Siatras, T., Papadopoulos, G., Mameletzi, D., Gerodimos, V., \& Kellis, S. (2003). Static and dynamic acute stretching effect on gymnasts' speed in vaulting. Pediatric Exercise Science, 15(4), 383-391. https://doi.org/10.1123/pes.15.4.383

Tatlıc1, A., \& Cakmakc1, O. (2019). The effects of acute dietary nitrate supplementation on anaerobic power of elite boxers. Medicina Dello Sport, 72(2), 225-233.

Turan, S., \& Çilli, M. (2016). Farklı Isınma Yöntemlerinin Olimpik Okçulukta Atış Performansına Etkisi. Online Türk Sağllk Bilimleri Dergisi, 1(1), 13-20.

Ünlü, G., \& Tatlıcı, A. (2018). Elit Güreşçilerde Proprioseptif Nöromuskuler Fasilitasyon (Pnf) Uygulamalarının Dinamik Denge Performansına Akut Etkileri. Sportif Bakış: Spor Ve Eğitim Bilimleri Dergisi, 57-63.

Yam, T. T. T., \& Fong, S. S. M. (2019). Y-balance test performance and leg muscle activations of children with developmental coordination disorder. Journal of Motor Behavior, 51(4), 385-393. https://doi.org/10.1080/00222895.2018.1485011

Yüksel, O., \& Akın, S. (2017). The Effects Of 8 Weeks Core Traınıng On Dynamıc Balance Of Elıte Level Badminton Players. European Journal of Physical Education and Sport Science, 3, 95-105

\section{Copyrights}

Copyright for this article is retained by the author, with first publication rights granted to the journal.

This is an open-access article distributed under the terms and conditions of the Creative Commons Attribution license (http://creativecommons.org/licenses/by/4.0/). 